\title{
Barriers to the career progression of women in banking sector in Albania. Do perceptions differ?
}

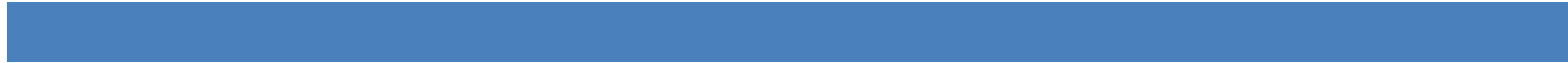

Elda Dollija $^{1}$ (ID Marinela Teneqexhi $^{2}$ (ID Sonela Stillo $^{3}$

1 Dr., Department of Management, Faculty of Economy, University “Fan S. Noli”, Korçë, ALB ANIA, e-mail: eldacollaku@yahoo.it

2 Assoc. Prof. Dr., University “Fan S. Noli", Korçë, ALB ANIA, e-mail: marinelapt@yahoo.com

3 Asst. Prof. Dr., University “Fan S. Noli”, Korçë, ALB ANIA, e-mail: sonelastillo@yahoo.com

Abstract

International statistics and studies emphasise the gender imbalance in high managerial levels. According to the literature review the undereppresentation of women in high levels is related to the "Glass Ceiling" phenomenon. These are barriers that hinder the career progression of women. According to the Gender Organization Structure model, these barriers are divided into three categories: Individual, Social and Organizational. The purpose of this study is to find out how do perceptions about these barriers vary according to five demographic variables (age, marital status, education, managerial position and experience) of women at managerial levels in commercial banks in Albania. The Kruskal-Wallis test is used to test the differences in perception of barriers. The results of the study show that: women's perceptions about individual barriers vary according only to the managerial level; women's perceptions about social barriers vary only according to age and maritual status; women's perceptions about organizational barriers vary only to marital status.
\end{abstract}

Keywords: women, career, glass ceiling, bank.

Jel codes: J16; J71; M14

\section{INTRODUCTION}

Recently, we are all witnessing a revolution of the role of women in society and especially in work environment. Over the past decades, women's participation in the workforce has increased. This phenomenon has been noted in developed countries as well as in developing countries (Davidson \& Burke, 2011). An important factor that has contributed to this phenomenon is the increasing number of educated women and their education in important proffessions (economics, law, engineering, etc.) (Mc.Donald, 2004). This has led to an increased number of women aspiring for career advancement.
Women are better educated and more active in the labour force than ever, and are increasingly working in managerial roles. Yet despite these gains, their representation in top positions in business still lags behind that of men (Burke \& Mattis, 2005; Davidson \& Burke, 2011, ILO report, 2019). International studies and statistics show the underrepresentation of women in senior managerial levels and decision making.

Although women worldwide contribute to economy and productivity, they continue to face many barriers

Citation/Atif: DOLLIJA E., TENEQEXHI M. \& STILLO S., (2021). Barriers to the career progression of women in banking sector in Albania. Do perceptions differ? Journal of Life Economics. 8(3):309-315, DOI: 10.15637/jlecon.8.3.04

Bu derginin içeriği Creative Commons Attribution-NonCommercial 4.0 Uluslararası Lisansı altında lisanslanmıı̧tır.

Content of this journal is licensed under a Creative Common Attribution-NonCommercial 4.0 International License. 
that prevent them from exploiting all their economic potential. This means that not only women are hindered, but economic progress is hindered, too. "Ensuring equal opportunities for women and men isn't just about doing the right thing, it makes economic sense " (Michelle Bachelet, UN Women's Executive Officer). ILO's survey concluded that over 57 per cent of respondents globally agreed that gender diversity initiatives improve business outcomes. They used several indicators to illustrate business outcomes including increased profitability and productivity; increased ability to attract and retain talent; enhanced company reputation; greater creativity, innovation and openness; and better ability to gauge consumer interest and demand (ILO report, 2019, pg. 19).

Women in Albania make up about \% nof the workforce, but they are under rappresented at senior management levels compared to their male counterparts both in public and private sectors. The overall Gender Equality Index for the Republic of Albania reached 60.4 in 2017, indicating a substantial gender gap. This phenomenon has caused many national and international debates and initiatives and confirms the need for stakeholders, including government, private sector, civil society and citizens to renew their commitment and efforts to achieve full gender equality. Indeed, the Gender Equality Index for Albania is 7 points below the EU-28 average (67.4), except in the domain of power, where Albania has higher gender parity than the EU28. We are all whitnessing the absence or low presence of women in posts such as: president, prome minister, ministries, etc. the same thing happens with the private sector. Men lead while women are in support positions. If we refer to the bankin sector in Albania, only 2 out of 16 commercial banks have women CEO.

International statistics and studies explain the under rappresentation of women in high managerial level by the glass ceiling barriers. The research question of the study is:

RQ: Do perceptions about barriers to women career progression in banking sector in Albania differ according to their demographic variables (age, marital status, education, managerial level, and experience in banking sector)?

\section{LITERATURE REVIEW}

Businesses are becoming aware that recruiting, retaining and developing qualified women is essential for their success and competitiveness (Wirth, 2001, p. 99, ILO report, 2019). So the main objective of equal opportunities programs is to remove barriers that reduce the contribution of women to the organization and hinder their career progress.

According to the GOS model (Gendered Organizatio- nal Structure) proposed by Fagenson (1993), barriers to women career progression are devided in three categories: individual, social and organizational barriers.

Individual barriers are related to internal individual factors, such as features, knowledge, attitude and inappropriate behaviour (Fagenson, 1986). According to this perspective, women possess some characteristics that are in conflict with the requirements of managerial roles and oppose their promotion to high levels of the organization hierarchy (Fagenson, 1986; Schein, 1975; Omar \& Davidson, 2001; Cleveland et al., 2000; Gutek, 1992; Carli et al. 2016; Kholis, 2017). Individual factors, such as age, educational level, skills, experience, and proffessionalism are closely related to career advancement. But gender stereotypes about what men can do that women can not afford, allow men to advance more in their careers. According to some stereotypes, women lack the necessary skills, such as assertiveness, motivation, ability and the opportunity to be part of networks, in order to progress in their career (Vecchio, 2002; Carli et al. 2016). Thus, the mere fact of being a woman is a potential barrier to advancing women in a career.

Societal barriers refer to beliefs in every society about the suitable roles for each gender. Some characteristics are thought to fit better for men and some others for women (Elamin \& Omair, 2010). Gender stereotypes are often used to support these traditional roles. These stereotypes are closely related to the surrounding culture reflecting opinions about the differences between women and men (Best, 2004, p. 11). Factors such as cultural, social, institutional practices, expectations and stereotypes about the role of men and women in society can influence the attitudes and behaviours of women at work (Fagenson, 1990; Kholis, 2017). In the study of Dervishi (2011) on women in Albania, it is claimed that patriarchal traditions constitute one of the basic reasons for gender discrimination in Albanian society. Social norms in the Albanian society consider women inferior to men. The husband is the principal column of the house and consequently he is the one who has to provide the main incomes for the family's livelihood. Meanwhile, the woman is supposed to take care of the children and the house. Such a job is always under estimated so that women's social status is lower than men'. Another study conducted by Kasimati and Gusho (2010) supports the same conclusions in the Albanian society.

Organizational barriers Studies on "glass ceiling" suggest that the organization's members views and attitudes (eg, women are not seen as leaders) and the social structure of the organization, affect the barriers that hinder the career advancement of women. According to literature on the glass ceiling (Oakley, 2000; Van Vianen, 2002; Kirai, 2013; Jamali et al., 2006; Di- 
movski et al., 2010; Tlaiss \& Kauser, 2010, Carli et al. 2016; Kholis, 2017), the organizational barriers are divided into two categories: (1) Corporation's Climate and Culture and (2) Corporate Practices. Corporation's Climate and Culture is related to the organization's norms and culture, policies, training systems, promotion and rewarding systems (Fagenson, 1990). According to Knuston \& Schmidgall (1999), corporate practices include training and development, networking, mentors, flexible working hours and other initiatives that balance work and family. While Oakley (2000) cites corporate policies and practices related to training and development, promotion and rewarding as the main components of "glass ceiling" that prevent women from climbing in high corporate levels.

\section{RESEARCH METHODOLOGY}

Based on an extensive international literature review, a questionnaire was designed pertaining to the objectives of the study. The questionnaire was divided into two sections. In the first section, the respondents were asked to indicate their demographic data related to their age, marital status, educational background, actual managerial position and experience in the banking sector.

The second section is focused on collecting data about women's perceptions of glass ceiling in their career advancement. The barriers are devided into 3 categories: Individual, Societal and Organizational barriers. Managerial women in the banking sector in Albania are asked to indicate their perceptions about the glass ceiling in a five-point Likert's scale [ranging from "strongly disagree" (1) to "strongly agree" (5)] for each barrier.

The aim of this study is to determine if perceptions of barriers to women career advancement differ related to 5 demographic variables, age, marital status, educational background, actual managerial position and experience in the banking sector.

According to statistics, there are 402 women managers working in the 16 commercial banks operating in Albania (table 1).

Table 1: The Population of The Study

\begin{tabular}{|c|c|}
\hline Managerial Level & Nr. of Women Manager \\
\hline Branch Manager & 201 \\
\hline Department Manager & 193 \\
\hline CEO/deputy CEO & 8 \\
\hline Total & 402 \\
\hline
\end{tabular}

The sampling method used in this study is non-probability purposive sampling procedure (Sunders et al., 2009). The sampling unit is women in three managerial levels (low, middle and high managerial level) in 9 out of 16 commercial banks operating in 9 different cities in Albania (NCB, Tirana Bank, Credins Bank,
Raiffeisen Bank, OTP Bank, FIBank, Union Bank, IntesaSanpaolo Bank, ProCredit Bank). For a more accurate orientation regarding the sample size, this study refers to the table published by Israel (2013). When the size of population is 400 , the appropriate sample size is 135 . The sampling size of the research is 135 respondents, representing $34 \%$ of the population.

The reliability of the questionnaire was ensured through Cronbach alpha coefficient. This test was used to assess the sustainability of the 3 independent study variables (IB - Individual Barriers; SB - Social Barriers; OB - Organizational Barriers). The values of the coefficients are greater than 0.7 showing a good consistency of the questionnaire (table 2). The collected data were tabulated on the computer and the final analysis was performed with SPSS 21 version.

Table 2: Cronbach Alfa

\begin{tabular}{|lc|}
\hline IB Cronbach Alpha & 0.723 \\
\hline SB Cronbach Alpha & 0.822 \\
\hline OB Cronbach Alpha & 0.832 \\
\hline
\end{tabular}

\subsection{Statistical Analysis and Data Findings}

Demographics Women managers of different group ages, marital status, educational background, managerial level and experience in the banking sector, are included in the study in order to explore their perceptions and opinions about the barriers to their career progress. Referring to the results of the study, women managers in the study have a relatively young age. Thus, most of them, 71\%, are 31-40 years old, followed by a 41-50 year old age group accounting for $22 \%$. Furthermore, most women managers in the study, $84 \%$, are married; $13 \%$ are single, and only $2 \%$ are divorced. Only $7 \%$ of women managers in this study have got a $\mathrm{PhD}, 51 \%$ have a Master degree and $42 \%$ have a Bachelor degree. Regarding the Managerial level, $53 \%$ of them are Branch manager, $44 \%$ are Department manager and only 4 of them (3\%) are CEO/ deputy CEO. Most women managers in the study, $51 \%$, have an average experience of 6-10 years in banking sector. 
Table 3: Demographics

\begin{tabular}{|c|c|c|c|}
\hline \multirow{4}{*}{ Age } & & Results & Percentage \\
\hline \multirow{4}{*}{ Marital status } & $<30$ & 3 & $2 \%$ \\
\cline { 2 - 4 } & $31-40$ & 96 & $71 \%$ \\
\cline { 2 - 4 } & $41-50$ & 30 & $22 \%$ \\
\cline { 2 - 4 } & $>50$ & 6 & $4 \%$ \\
\cline { 2 - 4 } & Single & 18 & $13 \%$ \\
\cline { 2 - 4 } & Divorced & 114 & $84 \%$ \\
\hline \multirow{3}{*}{$\begin{array}{c}\text { Educational } \\
\text { background }\end{array}$} & Widow & 0 & $2 \%$ \\
\cline { 2 - 4 } & Machelor & 57 & $42 \%$ \\
\cline { 2 - 4 } & Master, & 69 & $51 \%$ \\
\hline \multirow{3}{*}{\begin{tabular}{c} 
Managerial level \\
Branch \\
\cline { 2 - 3 }
\end{tabular}} & $\begin{array}{c}\text { Department } \\
\text { manager }\end{array}$ & 60 & $71 \%$ \\
\cline { 2 - 4 } & $\begin{array}{c}\text { CEO/ } \\
\text { deputy CEO }\end{array}$ & 4 & $53 \%$ \\
\hline \multirow{3}{*}{$\begin{array}{c}\text { Experience in } \\
\text { banking sector }\end{array}$} & $<5$ years & 8 & $4 \%$ \\
\cline { 2 - 4 } & $6-10$ years & 66 & $51 \%$ \\
\cline { 2 - 4 } & $11-15$ years & 36 & $27 \%$ \\
\cline { 2 - 4 } & $>15$ years & 24 & $18 \%$ \\
\hline
\end{tabular}

The variables of the study (IB, SB, OB) are tested for their distribution by the Kolmogorov-Smirnov (K-S) test, where $\mathrm{p}>0.05$ indicates a normal distribution. The results of this test reported a value of less than 0.05 , indicating a non-normal distribution (Table 4).

Table 4: The normality test (K-S)

\begin{tabular}{|c|c|c|c|}
\hline \multirow{2}{*}{ Variable } & \multicolumn{3}{|c|}{$\begin{array}{c}\text { Kolmogorov- } \\
\text { Smirnov(a) }\end{array}$} \\
\cline { 2 - 4 } & Statistic & Df & Sig. \\
\hline IB & 0.035 & 114 & 0.095 \\
\hline SB & 0.41 & 114 & 0.112 \\
\hline OB & 0.78 & 114 & 0.211 \\
\hline
\end{tabular}

If the distribution of data is non-normal and all demographic variables have more than two states, the Kruskal-Wallis (K-W) non-parametric test is used for further analysis. The K-W test is used to see if perceptions of the barriers to women career progression (IB, $\mathrm{SB}, \mathrm{OB})$ differ depending on the 5 different demographic variables: age, marital status, education, position, experience.

\subsection{Perceptual Differences in Barriers According To Women's Age}

The K-W non-parametric statistical test is used to test whether women perceptions' about barriers to their career vary depending on their age. The results of this test show that only perceptions about social barriers vary depending on age $(\mathrm{SB}, \mathrm{Sig} .=0.010<0.05)$ (Table $5)$.

The average ranking results (Table 6) show that the age group that perceives most of these barriers (SB) is $31-40$ years old (average ranking $=74.10$ ), followed by the age group $<30$ years (the average ranking 62.00). By the increasing of the age, this barrier is perceived to be less obstructive by the women in this study.

Table 5: K-W the relationship between age and barriers

\begin{tabular}{|c|c|c|c|}
\hline & IB & SB & OB \\
\hline Chi square & 4.371 & 10.304 & 2.53 \\
\hline Df & 3 & 3 & 3 \\
\hline Asymp. Sig. & 0.224 & $\mathbf{0 . 0 1 0}$ & 0.47 \\
\hline
\end{tabular}

Table 6: Ing among ages andperceptions about barriers

\begin{tabular}{|c|c|c|}
\hline Age & $\mathrm{N}$ & $\begin{array}{c}\text { Average } \\
\text { ranking SB }\end{array}$ \\
\hline$<30$ & 3 & 62.00 \\
\hline $31-40$ & 96 & 74.10 \\
\hline $41-50$ & 30 & 51.00 \\
\hline$>50$ & 6 & 43.00 \\
\hline
\end{tabular}

\subsection{Perceptual Differences in Barriers According To Women's Marital Status}

The results of the $\mathrm{K}-\mathrm{W}$ test show that perceptions about social and organizational barriers vary depending on their marital status (SB, Sig. $=0.001<0.05$; OB, Sig. $=0.002<0.05)($ Table 7$)$.

The average ranking results (Table 8 ) show that both barriers (SB and $\mathrm{OB}$ ) are more perceived by divorced women (average ranking for $\mathrm{SB}=125.50$ and for $\mathrm{OB}$ $=128.00$ ) followed by single women (average ranking for $\mathrm{SB}=88.17$ and for $\mathrm{OB}=83.39$ ).

Table 7: K-W the relationship between marital statusand barriers

\begin{tabular}{|c|c|c|c|}
\hline & IB & SB & OB \\
\hline Chi square & 1.916 & 10.304 & 11.130 \\
\hline Df & 2 & 2 & 2 \\
\hline Asymp. Sig. & 0.384 & $\mathbf{0 . 0 0 1}$ & $\mathbf{0 . 0 0 2}$ \\
\hline
\end{tabular}

Table 8: Averages' ranking among marital status and perceptions about barriers

\begin{tabular}{|c|c|c|c|}
\hline $\begin{array}{c}\text { Marital } \\
\text { status }\end{array}$ & $\mathrm{N}$ & $\begin{array}{c}\text { Average } \\
\text { ranking SB }\end{array}$ & $\begin{array}{c}\text { Average } \\
\text { ranking OB }\end{array}$ \\
\hline Single & 18 & 88.17 & 83.39 \\
\hline Married & 114 & 62.67 & 63.99 \\
\hline Divorced & 3 & 125.50 & 128.00 \\
\hline
\end{tabular}

\subsection{Perceptual Differences in Barriers According To Women's Educational Background}

The results of the K-W test show that women's perceptions of the barriers to their career advancement do not differ according to their educational background (Table 9). 
Table 9: K-W the relationship between education and barriers

\begin{tabular}{|c|c|c|c|}
\hline & IB & SB & OB \\
\hline Chi square & 5.051 & 5.061 & 2.506 \\
\hline Df & 2 & 2 & 2 \\
\hline Asymp. Sig. & 0.080 & 0.080 & 0.286 \\
\hline
\end{tabular}

\subsection{Perceptual Differences in Barriers According To Women's Experience in Banking Sector}

The results of the K-W test show that women's perceptions of the barriers to their career advancement do not differ according to their experience in banking sector (Table 10).

Table 10: Relationship between experience and barriers

\begin{tabular}{|l|l|l|l|}
\hline & \multicolumn{1}{c|}{ IB } & \multicolumn{1}{c|}{ SB } & \multicolumn{1}{c|}{ OB } \\
\hline Chi square & 10.723 & 13.270 & 8.013 \\
\hline Df & 3 & 3 & 3 \\
\hline Asymp. Sig. & 0.113 & 0.204 & 0.146 \\
\hline
\end{tabular}

\subsection{Perceptual Differences in Barriers According To Women's Managerial Level}

The results of the K-W test show that only perceptions about individual barriers vary depending on managerial level $(\mathrm{IB}$, Sig. $=0.000<0.05)$ (Table 11$)$. The average ranking results (Table 12) show that individual barriers are perceived more by low managerial level (average ranking for IB $=89.57$ ), followed by middle managerial level (average ranking for IB $=60.62$ ) and less by high managerial level (average ranking for IB $=19.17$ )

Table 11: K-W the relationship between managerial level and barriers

\begin{tabular}{|c|c|c|c|}
\hline & IB & SB & OB \\
\hline Chi square & 21.208 & 7.171 & 7.437 \\
\hline Df & 2 & 2 & 2 \\
\hline Asymp. Sig. & $\mathbf{0 . 0 0 0}$ & 0.127 & 0.115 \\
\hline
\end{tabular}

Table 12: Averages' ranking among managerial level and perceptions about barriers

\begin{tabular}{|c|c|c|}
\hline $\begin{array}{c}\text { Managerial } \\
\text { level }\end{array}$ & $\mathrm{N}$ & $\begin{array}{c}\text { Average } \\
\text { ranking IB }\end{array}$ \\
\hline $\begin{array}{c}\text { Branch } \\
\text { manager }\end{array}$ & 72 & 89.57 \\
\hline $\begin{array}{c}\text { Department } \\
\text { manager }\end{array}$ & 69 & 60.62 \\
\hline $\begin{array}{c}\text { CEO/ deputy } \\
\text { CEO }\end{array}$ & 4 & 19.17 \\
\hline
\end{tabular}

\section{DISCUSSION}

Women's perceptions about barriers to their career progression are tested if they differ according to their demographic variables: age, marital status, education, managerial level, and experience in banking sector.
The results of the study show that women' perceptions about individual and organizational barriers do not differ according to their age. On the other hand, social barriers differ according to women's age. Young women $(<40$ years old $)$ are the age group that most perceive these barriers.

Women's perceptions about social and organizational barriers vary depending on their marital status. These barriers are most perceived by divorced women followed by single women and less by married women. Albanian women's percpetions about social and organizational barriers are contradictory to western women's perceptions. Women managers in western countries such as USA, England, Irland, Canada (Cross, 2010; Granleese, 2004; Greenhaus \& Parasuaman, 1999; Oakley, 2000), often decide not to get married to avoid the obstacles that may come from their spouses and family care. They are often forced to make the difficult choice of being single and not having children compared to their male counterparts, who in most cases are married and do have children (Powell \& Women, 2003). Contrary, Albanian women's perceptions are consistent with the results of eastern cultures. According to Burke (2008) even though the average age of managerial women in Turkish banks was 35 years old, $61 \%$ of them were married and they didn't perceive their spouses as barriers to their career progression. The same perceptions had managerial women is Australian banks too (Metz, 2003). Likewise, women leaders in the civil service in Kenya (Kirai, 2013), in an international company in Malaysia (Ismail \&Ibrahim, 2007), in Lebanese banks (Jamali et al., 2006; Tlais \& Kausser, 2010), do not consider marriage as a barrier to their career advancement.

The results of the study show that marriage does not constitute a barrier to women's career progress in the banking system in Albania, because most of them, $84 \%$, are married. Likewise, academic women in the academic career in Albania (Kalaja, 2013) claim that their husbands not only did not hinder them, but also supported them in their academic career.

The results of women managers in this study can be explained by the culture and tradition of Albanian society. Women in the study stated that they didn't have to be single and childless in order to make career progress. On the contrary, they commented that the culture of Albanian society attaches great importance to family. Marriage is a social necessity and women are under continuous pressure from their family and society to get married and have a family. Also, the interviewed women stated that their husbands had supported them in every step of their career and had never hindered their career progression.

On the other hand, women's educational background and their experience in banking sector do not influen- 
ce the perceptions of the barriers to their career advancement. According to the Human Capital theory (Becker, 1993), education level, training, experience and competencies, help employees advance in their career and have good performance as these factors help increase their skills and knowledge. The results of table 2 show that women managers in the banking system in Albania do not lack education and the necessary qualification for career advancement challenging thus the myth of the past that women lack the necessary level of education to be a leader (Betz \& Fitzgerald, 1987). Educational disbalance between men and women has changed. Evenmore, according to statistics, women are more educated than men because girls make up the major part of graduate students (Instat, 2019).

Many studies agree that women have difficulties advancing to senior management levels, even though they have proper education, experience, professionalism and good performance at work (Kirai, 2013; Burke \& Matis, 2005; Davidson \& Burke, 2000; Ragins et al., 1998; Burke et al., 2008). Meantime, only women's perceptions about individual barriers vary depending on their managerial level. These barriers are more perceived by low managerial level followed by middle managerial level and less by high managerial level.

\section{LIMITATIONS OF THE STUDY}

The study focuses only on the banking sector and its conclusions related to women's perceptions about barriers to their career progression cannot be generalized in other sectors in Albania.

There are very few studies in the Albanian reality related to womens' perveptions about barriers to their career progression which limits the basis for comparisons.

\section{RECOMMENDATIONS FOR OTHER RESEARCH}

Women's career is a multidimensional issue because it affects not only women, but it is related to businesses and government practices and policies and this way it affects the whole society. This study focuses in the differences of women's perceptions about barriers to the career progression of women in Albania according to their demographic variables. It is focused only in the banking sector. We recommend to extand the survey in other public and private sectors in Albania in order to do comperative analizes. We also recommend comparing women's versus men's perceptions about barriers to career progression. Other studies may focus on other aspects of women's career: objective or subjective career success, are women satisfied with their career, women's aspiration in their career, etc.

\section{REFERENCES}

BEST, D.L. (2004). Gender stereotypes. In: Ember, C.R. \& Ember, M. (Eds) Encyclopedia of Sex and Gender: Men and Women in the World's Cultures, Vol. I: Topics and Cultures A-K. Dordrecht: Kluwer Academic/Plenum Publishers

BURKE, R.J. \& MATTIS M.C. (2005). Supporting Women's Career Advancement Challenges and Opportunities. Edward Elgar Cheltenham, UK • Northampton, MA, USA

CARLI, L.; ALAWA, L.; LEE, W.; ZHAO, B. \& KIM. E. (2016). Stereotypes About Gender And Science: Women $\neq$ Scientists. Psychology of Women Quarterly, 40(2) 244-260, Sage, DOI: 10.1177/0361684315622645

CLEVELAND, J.N., STOCKDALE, M., \& MURPHY, K.R. (Eds). (2000). Women and Men in Organizations: Gender Issues at Work. Mahwah, NJ: Lawrence Erlbaum Associates.

DAVIDSON, M.J \& BURKE, R.J (2011). Women in Management Worldwide: Progress and Prospects, second edition, Gower

DERVISHI Z. (2011). Gratë në turbulencat e mendësive dhe realiteti politik, Analizë sociologjike e përfshirjes së grave në jetën politike. EMAl, Tiranë, (Women in the turbulence of mindset and political reality, sociological analysis of women's involvement in political life)

DIMOVSKI V., SKERLAVAJ M., MOK KIM MAN M. (2010). Comparative Analysis of Mid-Level Women Managers' Perception of the Existence of "Glass Ceiling" in Singaporean and Malaysian Organizations. International Business E Economics Research Journal, 9(8), $61-77$

ELAMIN A. M. \& OMAIR, K. (2010). Males Attitudes Towards Working Females in Saudi Arabia. Personnel Review, 39(6), $746-766$

FAGENSON, E. A. (1986). Women's Work Orientations: Something Old, Something New. Group and Organization Studies, 11, 75-100.

FAGENSON, E. A. (1990). Perceived Masculine and Feminine Attributes Examined As A Function of Individuals' Sex and Level in The Organizational Power Hierarchy: A Test of Four Theoretical Perspectives. Journal of Applied Psychology, 75(2), 204-211.

FAGENSON, E.A. (1993). Diversity in management: Introduction and the importance of women in management in Fagenson: Trends, Issues, and Challenges in Management Diversity, Sage Newbury Park,CA.

GUTEK, B., (1992). Women In Management: Change, Progress or An Ephemeral Phenomenon. In L.A. Hes- 
lop. The ties that bind, Ottawa, Canada: Proceeding of the Global Research Conference on Women and Management.

ILO report (2019). Women in Business and Management, The business case for change, https://www.ilo. org/wcmsp5/groups/public/---dgreports/---dcomm/--publ/documents/publication/wcms_700953.pdf (Accessed Date: 21.06.2021)

ISRAEL, G.D. (2013). —Determining Sample Size, PEOD6 University of Florida, IFAS Extension, http:// edis.ifas.ufl.edu.

JAMALI, D., SAFIEDDINE, A. \& DAOUK, M. (2006). The Glass Ceiling: Some Positive Trends from The Lebanese Banking Sector. Women in Management Review, 21(8), 625-642.

KASIMATI, M.\& GUSHO, A. (2010). Women In Management. Is The Albanian Way Different? Economic and Social Challenges and Problems.

KHOLIS, N. (2017). Barriers to Women's Career Advancement in Indonesian Academia: A Qualitative Empirical Study. Advances in Social Science, Education and Humanities Research (ASSEHR), Atlantis Press, volume 66

KIRAI M.N. (2013). Barriers to Women Career Progression in Kenya's Civil Service, phd dizertacion, http://ir. jkuat.ac.ke/bitstream/handle/123456789/1217/Nchabira, \%20Margaret $\% 20 \% 20$ Kirai $\%$ E2\%80\%93PHD $\% 20$ Human\%20Resource\%20Management-2013.pdf?sequence $=1$ (Accessed Date: 21.06.2021)

KNUSTON, B. \& SCHMIDGALL, R. (1999). Dimensions of The Glass Ceiling in The Hospitality Industry. Cornell Hotel and Restaurant Administration Quarterly, 40(6).

MCDONALD, I. (2004). Women in management: a historical perspective. Employee Relations, 26(3), 307319.

OAKLEY, J.G., (2000). Gender-based barriers to senior management positions: understanding the scarcity of female CEO's, Journal of Business Ethics, Vol. 27, No. 4, pp. 321-34

OMAR, A. \& DAVIDSON, M. J. (2001). “Women in management: A comparative cross-cultural overview. Cross Cultural Management: An International Journal, Vol. 8, No. 3/4, fq. 35-67

SCHEIN, V. E. (1975). Relationships Between Sex Role Stereotypes and Requisite Management Characteristics Among Female Managers. Journal of Applied Psychology 5789- 105 .

TLAISS H. \& KAUSER S. (2010). a, Perceived organizational barriers to women's career advancement in Leb- anon, Gender in Management: An International Journal, 25(6).

VAN VIANEN A. E. M. (2002). Illuminating The Glass Ceiling: The Role Of Organizational Culture Preferences. Journal of Occupational and Organizational Psychology, 75(3), 315-337.

VECCHIO R. P. (2002). Leadership and Gender Advantage. The Leadership Quarterly 13(6), 643-671.

WIRTH L. (2001). Breaking through the glass ceiling: Women in Management. Geneva International Labor Office. 